\title{
Desain Antena Mikrostrip UWB dengan Peningkatan Lebar Pita dan Karakteristik Triple Notch Band
}

\section{(Bandwidth Enhanced UWB Microstrip Antenna Design with Triple Notch Band Characteristics)}

\author{
Harfan Hian Ryanu ${ }^{1}$, Dhoni Putra Setiawan ${ }^{2}$, Edwar $^{3}$
}

\begin{abstract}
Ultra-Wideband Antenna (UWB) with its natural wideband characteristic is a good solution to answer the need of recent wireless technology development that requires the antenna to operate in multiple frequency services. However, the UWB antenna has a major issue related to electromagnetic interference from unused bands. Thus, it is required for the UWB antenna to be modified to overcome the electromagnetic interference problem. This paper discusses the design of UWB hexagonal monopole planar microstrip antenna with bandwidth enhancement characteristics using hexagonal shaped EBG and triple notch band characteristic using three different slots. The study was conducted by integrating an EBG structure with a hexagonal-shaped monopole planar antenna for the antenna to work at 2,8-16 GHz bandwidth. The combination of $L$-shaped, horizontal, and round-shaped slots with different lengths are also integrated into the patch to remove three frequency bands at WLAN (4,9-6,2 GHz), satellite downlink communication $(7,1-7,6$ GHz), and Direct Broadcasting Satellite (DBS) (12,2-12,7 GHz). This method was capable to enhance the bandwidth of the UWB antenna from $7,72 \mathrm{GHz}$ to $13,22 \mathrm{GHz}$ without changing other characteristics such as radiation patterns. The integration process of triple notch bands was also implemented without changing the overall dimension of the antenna, which is $35,6 \mathrm{~mm} \times 27,3 \mathrm{~mm}$.
\end{abstract}

Intisari-Antena Ultra-Wideband (UWB) dengan karakteristik natural pita lebar adalah solusi yang baik dalam memenuhi kebutuhan perkembangan teknologi nirkabel yang saat ini membutuhkan antena yang dapat beroperasi pada beberapa pita layanan sekaligus. Namun, antena UWB tidak terlepas dari permasalahan interferensi elektromagnetik pada beberapa layanan yang tidak digunakan. Oleh karena itu, diperlukan modifikasi pada antena UWB agar dapat mengatasi permasalahan interferensi elektromagnetik tersebut. Dalam makalah ini, perancangan antena mikrostrip UWB berbentuk heksagonal monopole planar dengan karakteristik peningkatan lebar pita menggunakan struktur Electromagnetic Band Gap (EBG) dan triple notch band dengan menggunakan tiga jenis slot telah dilakukan. Pengujian dilakukan dengan mengintegrasikan struktur EBG untuk dapat bekerja pada rentang lebar pita 2,8$16 \mathrm{GHz}$ pada antena, lalu menambahkan kombinasi slot berbentuk huruf $\mathrm{L}$, slot horizontal, dan slot melingkar dengan ukuran dimensi yang berbeda ke dalam patch untuk mendapatkan penolakan tiga pita frekuensi, yaitu pada frekuensi WLAN $(4,9-6,2 \mathrm{GHz})$, komunikasi downlink satelit $X$-Band

1,2,3 Program Studi S1 Teknik Telekomunikasi, Fakultas Teknik Elektro, Universitas Telkom, Jl. Telekomunikasi Terusan Buah Batu, Bandung, 40257 INDONESIA (tlp: 022-7564108; e-mail: ${ }^{1}$ harfanhr@telkomuniversity.ac.id,

${ }^{2}$ setiawandhoni@telkomuniversity.ac.id,

3edwarm@telkomuniversity.ac.id)
(7,1-7,6 GHz), dan komunikasi Direct Broadcasting Satellite (DBS) $(12,2-12,7$ GHz). Dengan metode ini, berhasil diperoleh peningkatan lebar pita antena UWB dari $7,72 \mathrm{GHz}$ menjadi sebesar 13,22 GHz, tanpa mengubah karakteristik pola radiasi antena. Penambahan tiga notch band juga berhasil diimplementasikan tanpa harus mengubah dimensi antena keseluruhan, yaitu sebesar $35,6 \mathrm{~mm} \times 27,3 \mathrm{~mm}$.

Kata Kunci-Antena UWB, Penolakan Pita, Struktur EBG, Peningkatan Lebar Pita, Monopole Planar.

\section{Pendahuluan}

Sejak Federal Communication Commision (FCC) merilis pita frekuensi 3,1-10,6 GHz yang digunakan untuk kebutuhan komersial Ultra-Wideband (UWB) pada tahun 2002 [1], teknologi UWB menjadi sangat populer untuk digunakan pada komunikasi indoor dan jarak dekat. Kepopuleran tersebut diakibatkan tidak lain karena perkembangan teknologi nirkabel dengan frekuensi layanan yang semakin beragam, sehingga dibutuhkan lebih dari satu antena yang beroperasi pada beberapa pita layanan sekaligus. Antena UWB dengan karakteristik pita lebar dapat menggantikan beberapa antena dengan pita sempit sehingga secara efektif dapat mengurangi jumlah antena.

Tantangan utama pada antena UWB adalah terdapatnya beberapa layanan yang berada pada pita sempit, seperti Wireless LAN (WLAN) pada pita frekuensi 5,15-5,85 GHz, komunikasi downlink satelit $X$-Band pada rentang pita 7,1-7,6 $\mathrm{GHz}$, dan komunikasi Direct Broadcasting Satellite (DBS) pada pita $11,7-12,5 \mathrm{GHz}$, yang mengakibatkan permasalahan interferensi elektromagnetik pada sistem UWB. Teknik konvensional yang dapat digunakan untuk mengatasi interferensi adalah dengan menggunakan perangkat filter, tetapi dengan konsekuensi menambah kompleksitas saat diintegrasikan ke dalam sistem. Oleh karena itu, fokus beberapa penelitian pada antena UWB adalah cara mengatasi interferensi elektromagnetik tanpa membuat sistem menjadi lebih kompleks.

Metode yang efektif untuk menghindari interferensi elektromagnetik adalah dengan menggunakan metode penolakan (notch band) pada frekuensi yang tidak diinginkan. Notch band dapat diperoleh dengan beberapa teknik, antara lain dengan menambahkan slot pada antena. Beberapa bentuk slot dapat digunakan untuk memperoleh notch band, antara lain slot bentuk S, bentuk M, dan bentuk L. Dengan menggabungkan beberapa jenis slot sekaligus, dapat diperoleh multi notch band pada antena UWB [2], sehingga interferensi elektromagnetik 
dapat diminimalkan. Selain itu, penolakan frekuensi juga dapat dilakukan dengan menggunakan struktur Electromagnetic Band Gap (EBG) pada patch/ground. EBG merupakan sebuah struktur periodik yang dapat melarang propagasi gelombang elektromagnetik pada rentang frekuensi tertentu. Dengan begitu, penolakan pita frekuensi dapat diperoleh dengan mengatur karakteristik struktur periodik dari EBG yang digunakan [3]. Selain digunakan untuk penolakan frekuensi, slot dan struktur EBG pada antena dapat juga digunakan untuk meningkatkan lebar pita. Dengan memotong slot pada ground plane, dapat dimunculkan frekuensi resonansi tambahan sehingga dapat meningkatkan lebar pita [4]. Peningkatan lebar pita juga dapat dilakukan dengan meletakkan struktur EBG yang berdekatan dengan feed line [5]. Beberapa pengembangan peningkatan lebar pita untuk antena heksagonal antara lain dengan menggunakan slot simetris pada ground plane [6], dan kombinasi fraktal [7], tetapi besar peningkatan lebar pita tidak terlalu signifikan.

Makalah ini mengusulkan rancangan antena UWB berbentuk monopole planar heksagonal dengan ground plane parsial dan mengintegrasikan filter frekuensi triple notch band pada pita frekuensi $5,15-5,85 \mathrm{GHz}$ (WLAN), 7,1-7,6 GHz (komunikasi downlink satelit $X$-Band), dan pita $12,2-12,7 \mathrm{GHz}$ (komunikasi DBS). Tiga jenis slot dengan ukuran yang berbeda ditambahkan ke patch untuk mendapatkan penolakan pita frekuensi. Selain itu, dilakukan juga peningkatan lebar pita dengan menggunakan struktur EBG berbentuk heksagonal. Hasil dari penambahan struktur EBG menunjukkan peningkatan lebar pita dari 7,72 GHz sampai 13,22 GHz. Gain maksimum antena diperoleh sebesar 4,8 dBi pada frekuensi 14 $\mathrm{GHz}$ dan efisiensi menunjukkan hasil yang baik dengan rentang $45 \%$ sampai $85 \%$.

\section{Metodologi}

\section{A. Antena Monopole Planar}

Antena monopole planar menjadi kandidat yang baik untuk digunakan sebagai komunikasi UWB karena memiliki karakteristik ukuran yang sederhana, ringan, serta proses pabrikasi yang mudah dan biaya yang rendah. Beberapa metode telah digunakan untuk membuat antena UWB pada monopole planar, antara lain dengan teknik ground plane parsial [2]-[3], antena slot [8], Coplanar Wave Guide (CPW) [9], atau kombinasi antara slot dan CPW [10]. Estimasi nilai lower frequency $\left(f_{L}\right)$ dari antena monopole planar secara umum dapat menggunakan (1) [11].

$$
f_{L}=\frac{7,2}{\{(L+r+p) \times k\}} G H z
$$

dengan $L, r, p$, dan $k$ secara berurutan adalah tinggi patch dalam $\mathrm{cm}$, jari-jari efektif antena dengan ekuivalensi monopole silinder, jarak antara patch dengan ground plane, dan nilai $k$ setara dengan nilai effective permittivity. Antena monopole planar pada dasarnya terdiri atas beberapa bentuk, antara lain bentuk persegi, melingkar, segitiga, dan heksagonal [11]. Bentuk heksagonal dipilih karena memiliki permukaan patch yang luas sehingga cocok untuk dilakukan penambahan slot

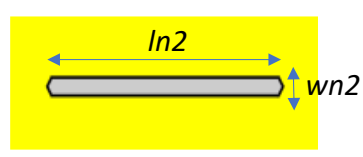

(a)

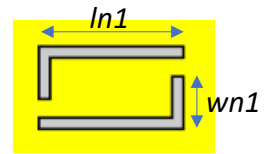

(b)

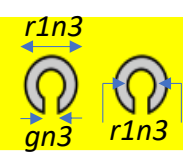

(c)
Gbr. 1 Struktur slot untuk penolakan frekuensi, (a) WLAN, (b) satelit $X$-band, (c) televisi satelit

notch band. Nilai $L, r$, dan $k$ untuk antena monopole heksagonal dapat diturunkan menggunakan (2)-(4):

$$
\begin{gathered}
L=\sqrt{3} a \\
r=\frac{3 a}{4 \pi} \\
k=\sqrt{\frac{\varepsilon_{r}+1}{2}}
\end{gathered}
$$

dengan $a$ adalah panjang sisi patch heksagonal dan $\varepsilon_{r}$ adalah relative permittivity bahan substrat. Dalam perancangan antena UWB ini, bahan substrat yang digunakan adalah FR-4 epoxy dengan nilai $\varepsilon_{r}=4,3$ dan ketebalan substrat 1,6 mm. Antena dicatu dengan teknik pencatuan microstrip line dan terhubung dengan konektor yang memiliki impedansi $50 \Omega$.

Untuk penerapan notch band, dilakukan implementasi slot pada patch antena. Hubungan antara panjang slot $(L)$ dengan frekuensi resonansi masing-masing frekuensi $\left(f_{\text {notch }}\right)$ adalah sesuai dengan (5):

$$
f_{\text {notch }}=\frac{c}{\{2 \times L \times k\}} G H z
$$

dengan $c$ adalah kecepatan cahaya dan $k$ setara dengan effective permittivity bahan sesuai pada (4) [12].

Pada makalah ini diusulkan tiga jenis slot, yaitu slot berbentuk horizontal, slot berbentuk sepasang huruf L, dan slot berbentuk melingkar. Gbr. 1 memperlihatkan konfigurasi slot untuk masing-masing notch band, dengan nilai panjang $\left(L_{\text {notch }}\right)$ masing-masing slot dapat diperoleh menggunakan (6)-(8).

$$
\begin{gathered}
L_{\text {notch(horizontal) }}=\ln 2 \\
L_{\text {notch(sepasang huruf } L)}=\ln 1+w n 1 \\
L_{\text {notch(melingkar) }}=2 * \pi *\left(\frac{r 1 n 3+r 2 n 3}{2}\right)-g n 3 .
\end{gathered}
$$

\section{B. Usulan Desain/Perancangan Antena}

Perancangan antena dimulai dengan perhitungan dimensi antena menggunakan persamaan matematis. Desain antena terdiri atas tiga tahapan utama sesuai pada Gbr. 2 .

1) Antena UWB Monopole Planar Heksagonal: Pada tahapan pertama konfigurasi A dilakukan perhitungan dimensi patch dari monopole planar bentuk heksagonal menggunakan (1)-(4). Antena UWB menggunakan ground plane parsial yang dicatu dengan microstrip line $50 \Omega$.

2) Antena UWB dengan Heksagonal EBG: Pada tahapan kedua konfigurasi $\mathrm{B}$, antena UWB yang telah berhasil dirancang dipadukan dengan struktur EBG untuk mendapatkan karakteristik peningkatan lebar pita. Sesuai pada Gbr. 3, 


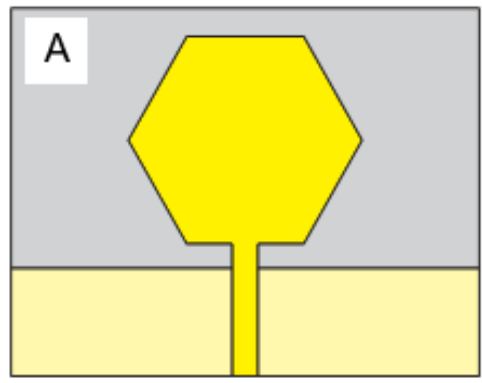

(a)

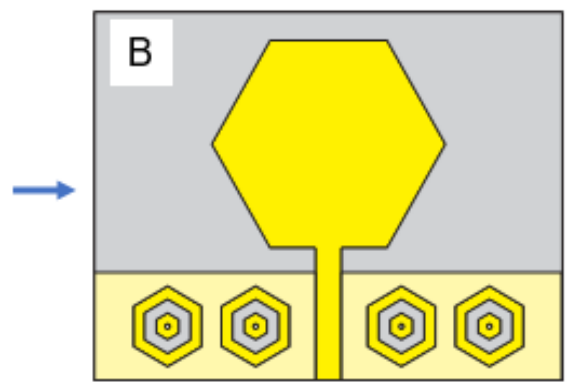

(b)

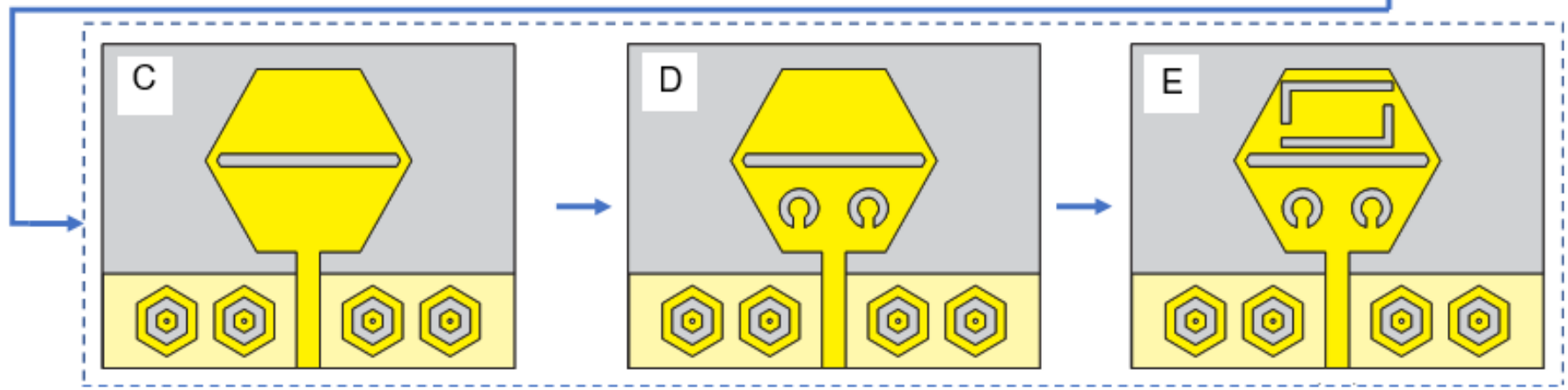

(c)

Gbr. 2 Tahapan perancangan antena yang diusulkan, (a) antena A UWB heksagonal, (b) antena B UWB heksagonal dengan EBG untuk peningkatan lebar pita, (c) penambahan slot untuk mendapatkan karakteristik triple notch band (antena C, D, dan E).

$b$

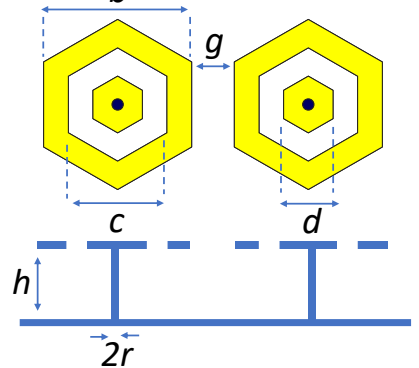

Gbr. 3 Struktur sel EBG heksagonal dan rangkaian ekuivalen $L C$.

struktur EBG berbentuk patch heksagonal dengan cincin slot yang juga berbentuk heksagonal di dalamnya dan sebuah via yang terhubung dengan ground plane pada bagian tengah EBG. Struktur EBG disusun horizontal dengan gap 1,5 mm. Parameter lain dari EBG heksagonal adalah $b=3 \mathrm{~mm}, c=2$ $\mathrm{mm}, d=1 \mathrm{~mm}$, dan $r=0,2 \mathrm{~mm}$. Struktur EBG heksagonal dapat digambarkan sebagai rangkaian $L C$. Induktansi $L$ muncul karena arus yang mengalir pada pin metal, sedangkan kapasitansi $C$ didapat dari gap antara sel yang berdekatan [13].

3) Antena UWB dengan Heksagonal EBG dan Triple Notch Band Slot: Pada tahap akhir dilakukan implementasi slot pada EBG secara bertahap pada konfigurasi C sampai E untuk mendapatkan karakteristik filter frekuensi yang diinginkan. Pertama, slot horizontal pada konfigurasi C dipasang untuk mendapatkan penolakan pada pita frekuensi WLAN $(5,15-5,85$ $\mathrm{GHz}$ ). Konfigurasi D menambahkan sepasang slot berbentuk melingkar untuk mendapatkan filter pada pita frekuensi DBS $(12,2-12,7 \mathrm{GHz})$. Pada tahap akhir konfigurasi E, dilakukan
TABEL I

Perbandingan PERHITUNGAN RUMUS DAN HASIL SimUlasi PANJANG SLOT

\begin{tabular}{|c|c|c|c|}
\hline Karakteristik & WLAN & $\begin{array}{c}\text { Satelit } \boldsymbol{X} \text { - } \\
\text { Band }\end{array}$ & DBS \\
\hline Lebar pita layanan (GHz) & $5,15-5,82$ & $7,15-7,75$ & $12,2-12,7$ \\
\hline $\begin{array}{c}\text { Frekuensi tengah } \text { notch } \\
\text { (GHz) }\end{array}$ & 5,5 & 7,45 & 12,45 \\
\hline Lebar pita simulasi (GHz) & $4,67-6,01$ & $7,17-7,79$ & $12,01-12,89$ \\
\hline $\begin{array}{c}\text { Frekuensi tengah } \text { notch } \\
\text { simulasi (GHz) }\end{array}$ & 5,46 & 7,42 & 12,43 \\
\hline $\begin{array}{c}\text { Perhitungan rumus } \\
\text { panjang } \text { slot (mm) }\end{array}$ & 16,75 & 12,37 & 7,40 \\
\hline $\begin{array}{c}\text { Hasil optimasi simulasi } \\
\text { panjang slot (mm) }\end{array}$ & 15,8 & 13,10 & 7,00 \\
\hline
\end{tabular}

implementasi filter pada pita frekuensi satelit $X$-Band $(7,1-7,6$ $\mathrm{GHz}$ ) dengan menggunakan sepasang slot berbentuk huruf L. Tujuan diterapkannya notch band adalah untuk menghindari interferensi antena UWB terhadap layanan pita sempit seperti WLAN, satelit $X$-band, dan juga layanan DBS. Panjang masing-masing slot sesuai Gbr. 1 dihitung berdasarkan (5)-(8). Tabel I memperlihatkan perbandingan antara perhitungan panjang slot berdasarkan hasil perhitungan teori dengan hasil optimasi menggunakan software simulasi CST Studio.

\section{Alat dan Bahan}

Bahan substrat yang digunakan adalah FR-4 epoxy dengan nilai $\varepsilon_{r}=4,3$ dan ketebalan substrat $1,6 \mathrm{~mm}$. Antena dicatu dengan teknik pencatuan microstrip line dan terhubung dengan konektor yang memiliki impedansi $50 \Omega$. Gbr. 4 dan Tabel II memperlihatkan rancangan akhir dari antena monopole dengan pelebaran pita dan triple notchband dan nilai yang telah 


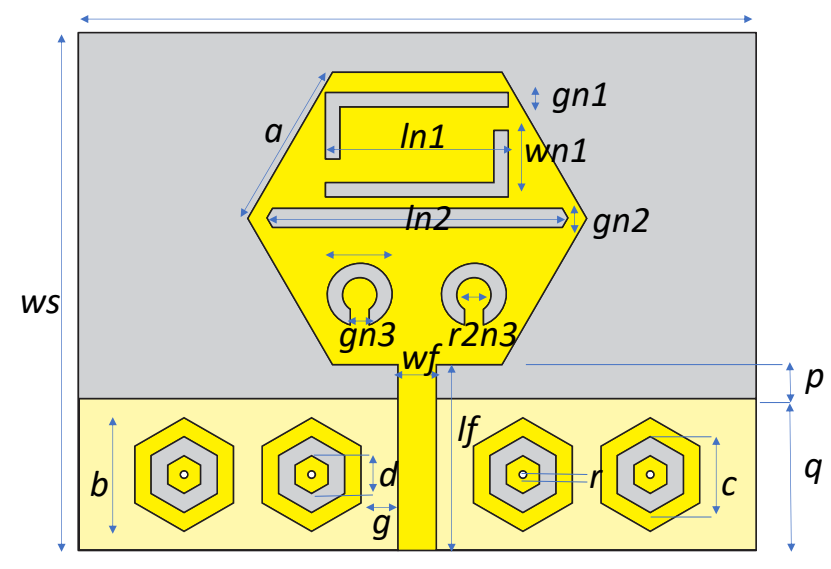

Gbr. 4 Geometri antena monopole planar heksagonal yang diusulkan.

TABEL II

NILAI PARAMETER YANG TELAH DIOPTIMASI

\begin{tabular}{|c|c||c|c|}
\hline Parameter & Nilai (mm) & Parameter & Nilai (mm) \\
\hline$a$ & 17,8 & $\ln 1$ & 9,6 \\
\hline$b$ & 3 & $\ln 2$ & 15,8 \\
\hline$c$ & 2 & $p$ & 1,8 \\
\hline$d$ & 1 & $q$ & 8,0 \\
\hline$g$ & 1,55 & $r$ & 0,2 \\
\hline$g n 1$ & 0,75 & $r \ln 3$ & 1,66 \\
\hline$g n 2$ & 1 & $r 2 n 3$ & 0,91 \\
\hline$g n 3$ & 0,75 & $w f$ & 2 \\
\hline$l f$ & 9,8 & $w s$ & 27,3 \\
\hline$l s$ & 35,6 & $w n 1$ & 3,5 \\
\hline
\end{tabular}

dioptimasi. Antena disimulasikan menggunakan software CST Studio. Hasil simulasi koefisien refleksi pada kelima tahapan perancangan antena ditunjukkan pada Gbr. 5 dan Tabel III. Pada hasil simulasi dapat dilihat keseluruhan antena bekerja pada rentang 3,1-10,6 GHz sehingga memenuhi karakteristik UWB menurut FCC. Selain itu, koefisien refleksi pada konfigurasi antena B sampai E pada Gbr. 2 yang menggunakan heksagonal EBG dapat dikonfirmasi terdapat peningkatan lebar pita sebesar > 5,2 GHz dibandingkan konfigurasi awal antena A tanpa menggunakan struktur EBG. Penolakan frekuensi pada masing-masing tahapan juga dikonfirmasi oleh hasil simulasi pada antena $\mathrm{C}$ sampai $\mathrm{E}$.

\section{HASIL DAN PEMBAHASAN}

Studi parametrik dilakukan untuk mengoptimasi antena dari perhitungan matematis. Beberapa studi parametrik yang telah dilakukan antara lain mengetahui efek jarak antara patch dengan ground plane, mengetahui jarak antar sel EBG heksagonal, serta mengetahui pengaruh panjang dan lebar slot.

Pada studi parametrik pertama, dari (1) sampai (4) dapat diperoleh nilai panjang sisi $a=6,4 \mathrm{~mm}$ dan jarak patch dengan ground plane $p=1,8 \mathrm{~mm}$ agar antena UWB dapat bekerja pada frekuensi 3,1-10,6 GHz. Namun, hasil simulasi pada Gbr. 6 menunjukkan bahwa nilai frekuensi bawah masih berada di atas $3 \mathrm{GHz}$ dan antena belum bekerja sesuai dengan spesifikasi yang diinginkan. Berdasarkan (1) sampai (4) dapat dilihat besar frekuensi bawah tergantung dan berbanding terbalik terhadap nilai $a$ dan $p$. Dengan demikian, beberapa alternatif untuk menurunkan frekuensi bawah adalah dengan memperbesar

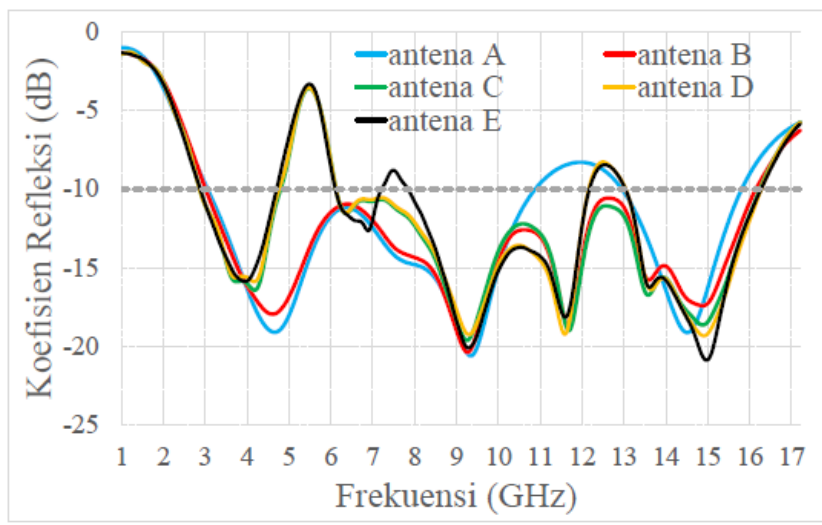

Gbr. 5 Hasil koefisien refleksi masing-masing tahapan perancangan antena.

TABEL III

SUMMARY LEBAR PITA DAN JUMLAH NOTCH BAND MASING-MASING TAHAPAN PERANCANGAN ANTENA

\begin{tabular}{|c|c|c|c|}
\hline Konfigurasi & $\begin{array}{c}\text { Frekuensi } \\
\text { Kerja (GHz) }\end{array}$ & $\begin{array}{c}\text { Lebar pita } \\
(\mathbf{G H z})\end{array}$ & $\begin{array}{c}\text { Jumlah } \\
\text { Notch } \text { Band }\end{array}$ \\
\hline Antena A & $3,04-10,76$ & 7,72 & 0 \\
\hline Antena B & $2,99-15,97$ & 12,98 & 0 \\
\hline Antena C & $2,89-16,02$ & 13,13 & 1 \\
\hline Antena D & $2,86-16,08$ & 13,22 & 2 \\
\hline Antena E & $2,86-16,08$ & 13,22 & 3 \\
\hline
\end{tabular}

dimensi patch atau meninggikan ground plane sehingga jarak antara ground plane dengan patch semakin kecil. Studi parametrik difokuskan dengan menyimulasikan variasi panjang sisi patch heksagonal $a$ dengan nilai $6,4 \mathrm{~mm}, 6,9 \mathrm{~mm}, 7,4 \mathrm{~mm}$, 7,9 mm, dan 8,9 mm. Hasil simulasi pada Gbr. 6 mengonfirmasi bahwa dengan memperbesar panjang sisi patch, didapatkan pergeseran frekuensi kerja menjadi lebih kecil. Selain itu, apabila diambil koefisien refleksi dibawah -10 dB sebagai batas lebar pita, pada panjang sisi heksagonal $8,9 \mathrm{~mm}$ juga diperoleh matching impedance yang baik pada seluruh pita frekuensi 3,1-10,6 GHz, dibandingkan dengan nilai $a$ yang lain.

Dalam hal pengaruh perubahan jarak patch dengan ground plane $(p)$ terhadap frekuensi kerja antena, nilai $p$ divariasikan dari $0,8 \mathrm{~mm}, 1,3 \mathrm{~mm}, 1,8 \mathrm{~mm}, 2,3 \mathrm{~mm}$, dan $2,8 \mathrm{~mm}$. Gbr. 7 mengonfirmasi bahwa semakin dekat jarak antara patch dengan ground plane, maka batas bawah frekuensi pada koefisien refleksi $-10 \mathrm{~dB}$ semakin menurun. Namun, dapat diamati juga bahwa batas frekuensi atas pertama pada nilai $p=0,8 \mathrm{~mm}$ yang menyentuh nilai koefisien refleksi $-10 \mathrm{~dB}$ berada pada frekuensi 5,5 $\mathrm{GHz}$, sehingga belum memenuhi spesifikasi UWB menurut FCC. Berdasarkan Gbr. 6 dan Gbr. 7, nilai $a=$ $8,9 \mathrm{~mm}$ dan $p=1,8 \mathrm{~mm}$ diambil sebagai hasil optimasi karena memiliki rentang frekuensi kerja pada batas koefisien refleksi sebesar $-10 \mathrm{~dB}$ sesuai spesifikasi UWB pada FCC dan juga memiliki impedance matching yang baik pada pita lebar.

Pada studi parametrik yang kedua, dilakukan analisis pengaruh EBG terhadap peningkatan lebar pita antena. Metode Suspended Transmission Line digunakan untuk memahami efek dari struktur EBG pada frekuensi resonansi [14]-[16]. Susunan sel heksagonal disimulasikan di bawah sebuah saluran transmisi dengan dua buah port sesuai Gbr. 8. Struktur sel EBG 


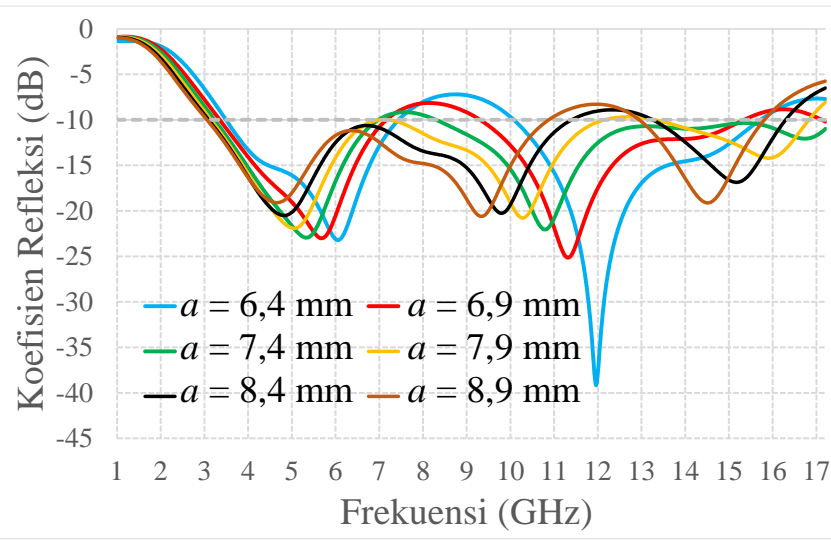

Gbr. 6 Pengaruh perubahan sisi patch heksagonal terhadap frekuensi kerja antena.

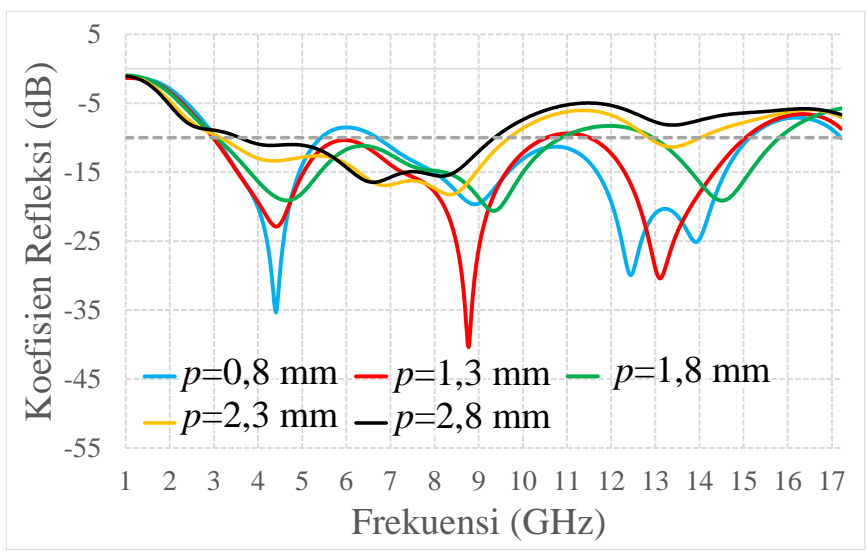

Gbr. 7 Pengaruh perubahan jarak antara patch dan ground plane terhadap frekuensi kerja antena.

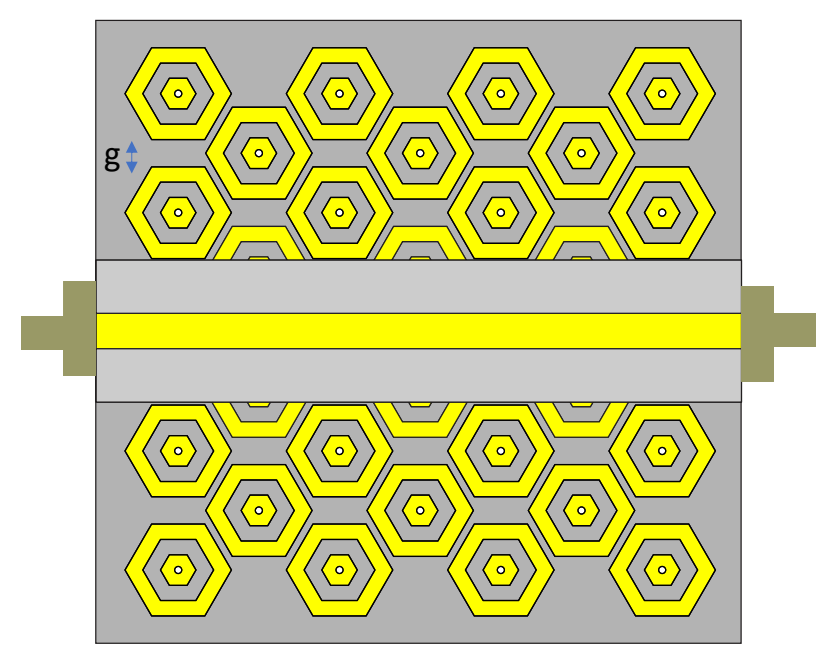

Gbr. 8 Susunan EBG pada saluran transmisi suspended.

tersebut akan melakukan penolakan transmisi pada saluran, ditandai dengan penurunan koefisien transmisi (parameter $S_{21}$ ) pada pita frekuensi tertentu. Besarnya penolakan frekuensi dapat diamati pada daerah dengan $S_{21}<-10 \mathrm{~dB}$. Untuk mendapatkan peningkatan lebar pita, daerah notch band pada struktur EBG didesain bersebelahan dengan pita frekuensi antena UWB. Apabila EBG diintegrasikan pada lapisan

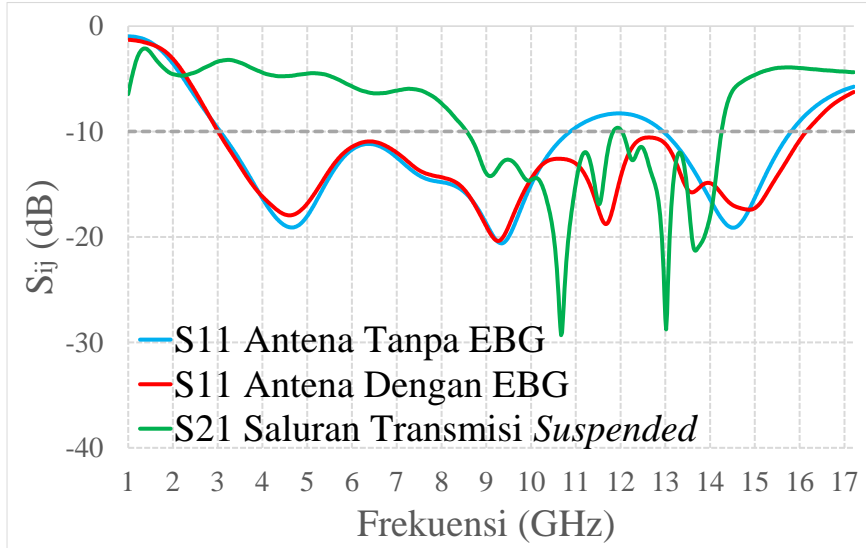

Gbr. 9 Perbandingan $S_{11}$ antena tanpa EBG, $S_{11}$ antena dengan EBG, dan $S_{21}$ saluran transmisi suspended.

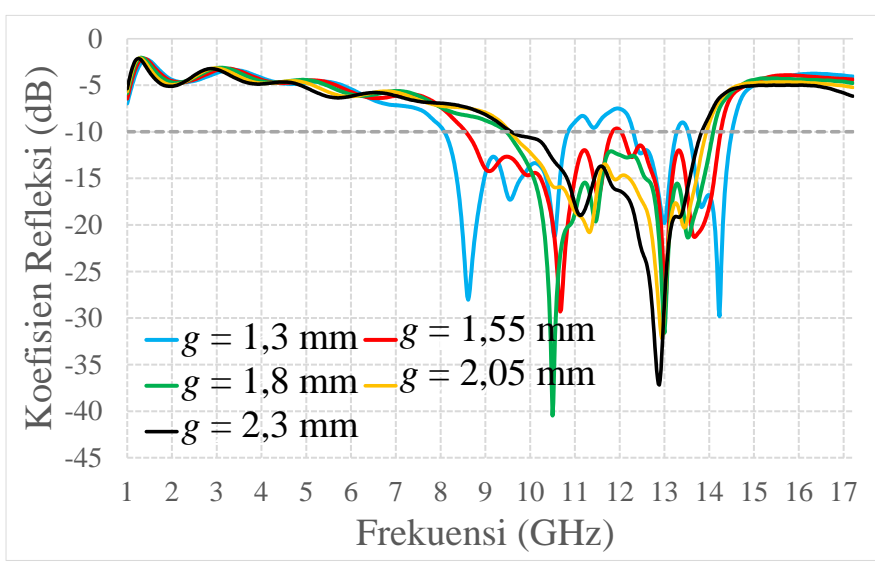

Gbr. 10 Pengaruh jarak antar sel pada struktur EBG heksagonal slot ring terhadap lebar notch band dan frekuensi tengah penolakan transmisi pada saluran.

substrat yang sama dengan patch, karakteristik pita yang lebih lebar dapat diperoleh tanpa perlu mengubah karakteristik antena yang lain, seperti pola radiasi [14]. Pada Gbr. 9, dapat dilihat bahwa peningkatan lebar pita terjadi pada frekuensi $10,7-12,8 \mathrm{GHz}$, tetapi pada frekuensi $10,57 \mathrm{GHz}$ dan 12,87 $\mathrm{GHz}$, koefisien refleksi $\left(S_{11}\right)$ mendekati nilai $-10 \mathrm{~dB}$ karena pada frekuensi tersebut terjadi notch band pada saluran transmisi suspended dengan nilai $S_{21}$ secara berurutan adalah sebesar -29,12 dB dan $-28,76 \mathrm{~dB}$.

Dengan menggunakan struktur yang sama pada Gbr. 8, jarak antar sel $(g)$ dianalisis dengan variasi jarak $1,3 \mathrm{~mm}, 1,55 \mathrm{~mm}$, 1,8 mm, 2,05 mm, dan 2,3 mm. Pada Gbr. 10 terlihat bahwa jarak antar sel pada struktur EBG heksagonal slot ring memengaruhi lebar notch band dan juga frekuensi tengah penolakan pada saluran. Dengan demikian, jarak antar sel sebesar 1,55 mm dipilih karena memiliki lebar pita resonansi paling berdekatan dengan konfigurasi antena UWB yang dirancang.

Pada studi parametrik yang ketiga, dilakukan analisis pengaruh perubahan panjang slot dan lebar slot. Berdasarkan (5) sampai (8) dapat diamati bahwa besarnya panjang slot berbanding terbalik dengan frekuensi resonansi. Masingmasing panjang slot pada frekuensi tengah pita yang ditolak 


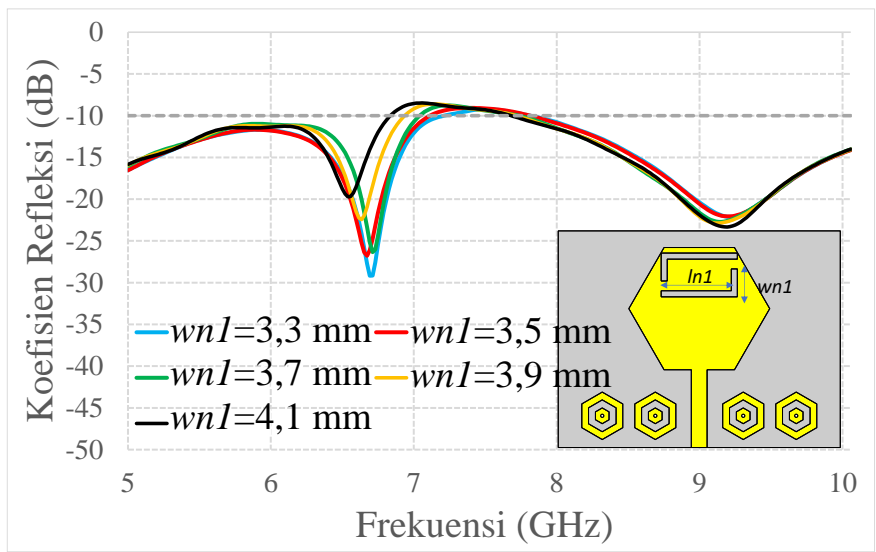

Gbr. 11 Pengaruh perubahan panjang slot bagian atas pada pergeseran frekuensi tengah penolakan pita frekuensi satelit $X$-Band.

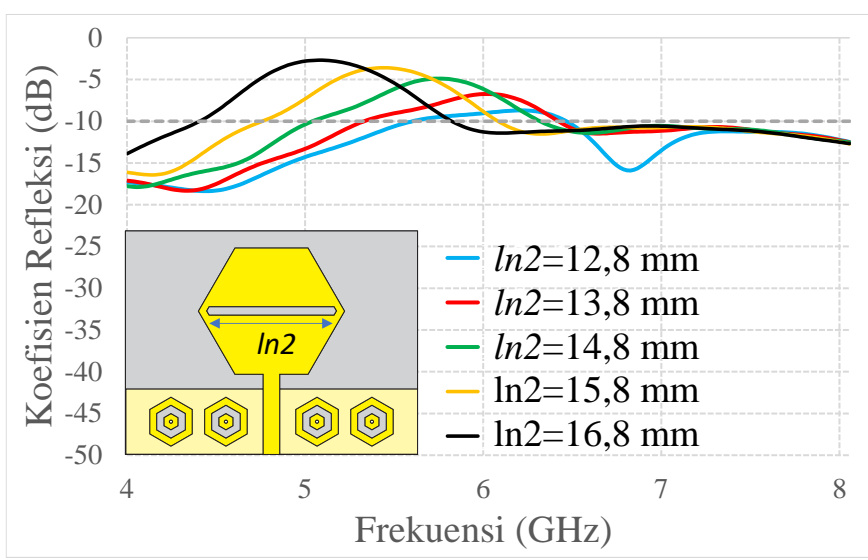

Gbr. 12 Pengaruh perubahan panjang slot bagian tengah pada pergeseran frekuensi tengah penolakan pita frekuensi WLAN.

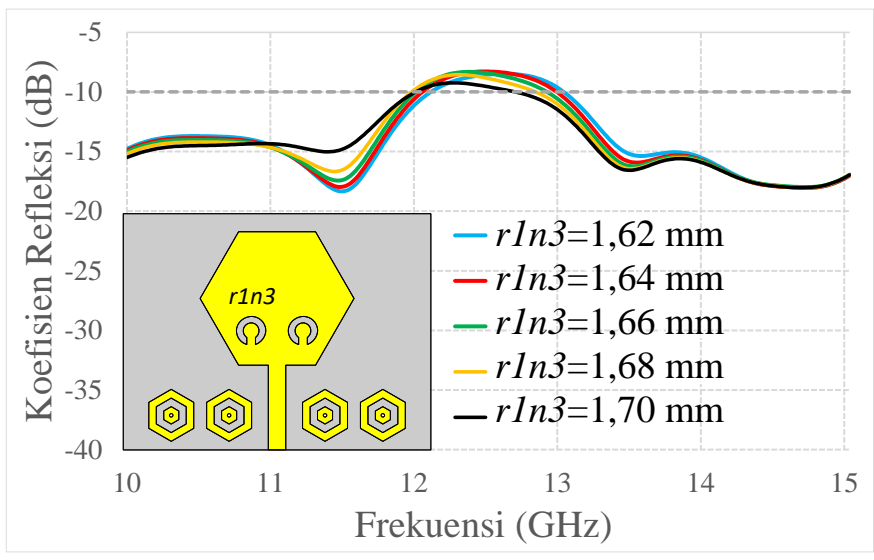

Gbr. 13 Pengaruh perubahan jari-jari slot bagian bawah pada panjang slot melingkar terhadap pergeseran frekuensi tengah penolakan pita frekuensi komunikasi DBS.

dapat dilihat pada Tabel I. Optimasi dilakukan dengan mengubah nilai tersebut menjadi lebih besar atau lebih kecil sampai didapatkan hasil yang diinginkan. Pada slot yang pertama, parametrik studi dilakukan dengan mengubah panjang lengan slot $\mathrm{L}(w n l)$ dengan variasi $3,3 \mathrm{~mm}, 3,5 \mathrm{~mm}, 3,7 \mathrm{~mm}$, 3,9 mm, dan 4,1 mm. Gbr. 11 memperlihatkan bahwa semakin panjang slot, frekuensi tengah penolakan pada pita satelit $X$ Band akan semakin mengecil. Sementara itu, pada slot yang

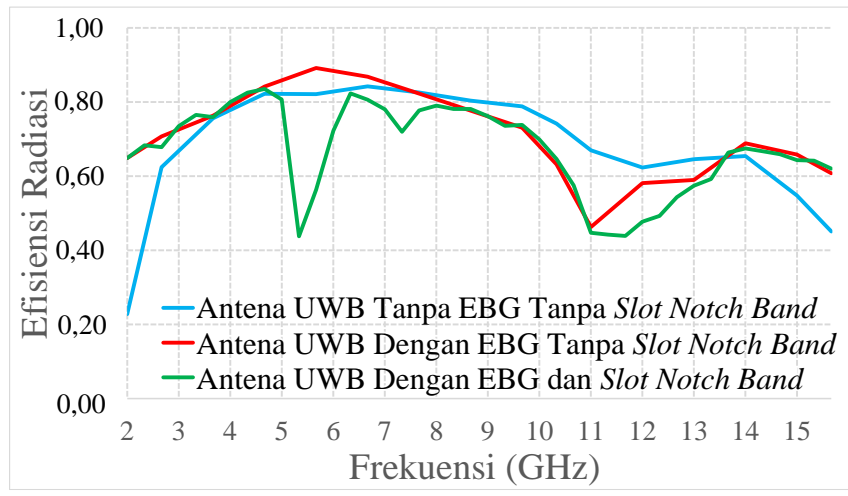

Gbr. 14 Efisiensi antena berdasarkan tahapan perancangan.

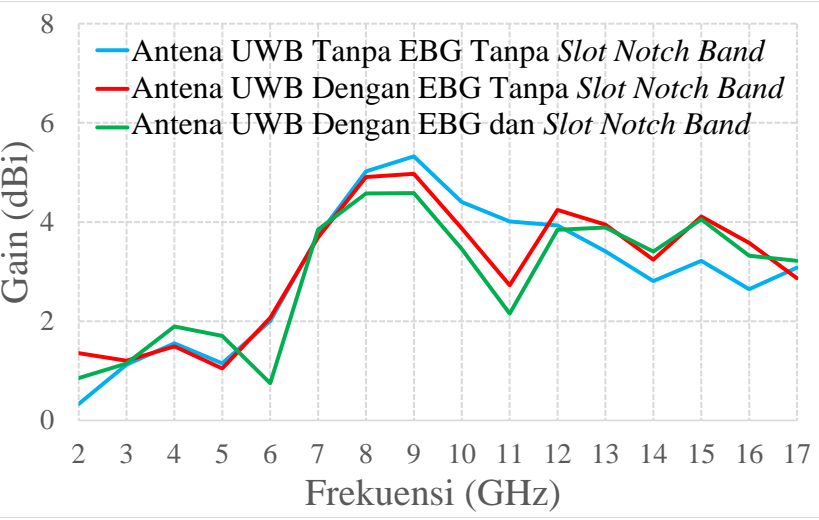

Gbr. 15 Gain antena berdasarkan tahapan perancangan.

kedua di bagian tengah, dianalisis perubahan panjang slot $\ln 2$ dengan variasi $12,8 \mathrm{~mm}, 13,8 \mathrm{~mm}, 14,8 \mathrm{~mm}, 15,8 \mathrm{~mm}$, dan 16,8 mm. Sesuai Gbr. 12, semakin panjang slot $\ln 2$, semakin kecil nilai frekuensi tengah penolakan pada pita WLAN. Lalu, pada Gbr. 13 dapat dilihat bahwa dengan pengaturan jari-jari slot rln3 dapat memengaruhi panjang slot berbentuk melingkar sehingga memengaruhi frekuensi tengah penolakan pada pita DBS. Hasil dari ketiga analisis slot tersebut mengonfirmasi (5) yang secara matematis menyatakan bahwa semakin panjang slot, penolakan terjadi pada frekuensi yang lebih kecil, dan sebaliknya.

Berdasarkan hasil studi parametrik, nilai $w n 1=3,5 \mathrm{~mm}$ digunakan pada slot bagian atas karena memiliki lebar pita dan frekuensi tengah mendekati pita layanan satelit X-Band, sedangkan panjang slot $\ln 2=15,8 \mathrm{~mm}$ digunakan pada slot bagian tengah karena paling mendekati lebar pita frekuensi WLAN. Sementara itu, untuk slot bagian bawah, nilai $r \ln 3=$ 1,66 mm digunakan karena paling mendekati lebar pita frekuensi DBS. Hasil optimasi dari studi parametrik dijadikan acuan bagi dimensi akhir antena yang disajikan pada Tabel II.

Setelah didapatkan dimensi akhir antena sesuai Tabel II, karakteristik antena selanjutnya ditinjau dari parameter radiasi, seperti efisiensi, gain, dan pola radiasi. Pada karakteristik efisiensi, seperti ditunjukkan pada Gbr. 14, antena memiliki efisiensi yang cukup baik dengan nilai efisiensi berkisar antara $45 \%$ sampai dengan $85 \%$ pada frekuensi kerja UWB. Selain itu, pada antena dengan slot, dapat diamati bahwa terdapat penurunan efisiensi antena, yaitu pada frekuensi WLAN dengan efisiensi sebesar $43 \%$, DBS sebesar $44 \%$, dan pada 


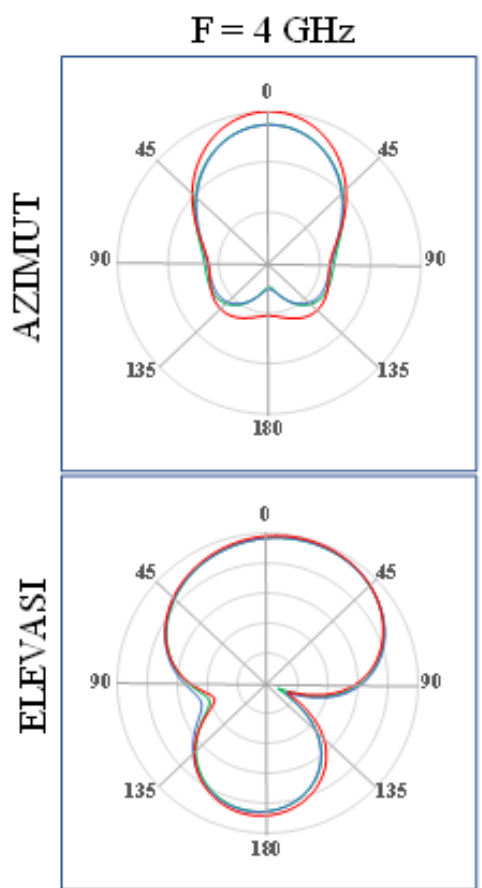

(a)

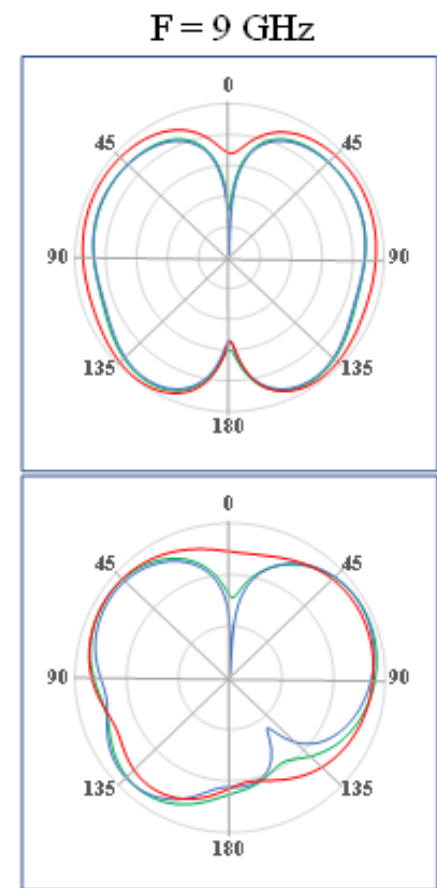

(b)

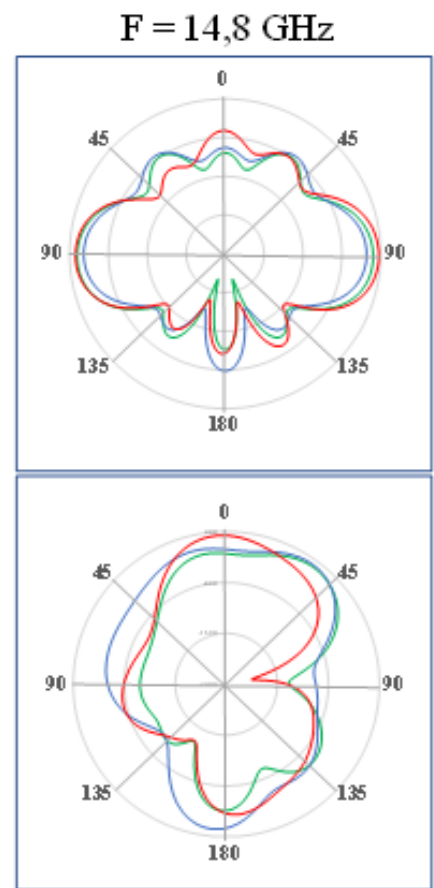

(c)

- Antena UWB dengan EBG tanpa Penolakan Pita

- Antena UWB tanpa EBG tanpa Penolakan Pita - Antena UWB dengan EBG dan Penolakan Pita

Gbr. 16 Pola radiasi antena arah azimut dan elevasi, (a) frekuensi $4 \mathrm{GHz}$, (b) frekuensi $9 \mathrm{GHz}$, (c) frekuensi 14,8 GHz.

satelit $X$-Band dengan efisiensi sebesar $71 \%$. Hal ini sejalan dengan nilai koefisien refleksi pada masing-masing tahapan, sesuai pada Gbr. 5. Koefisien refleksi > $-10 \mathrm{~dB}$ pada frekuensi notch band mengakibatkan efisiensi radiasi antena menjadi lebih kecil dibandingkan frekuensi di sekitarnya.

Selain oleh faktor notch band, penurunan efisiensi juga dipengaruhi oleh struktur EBG. Sesuai dengan Gbr. 14, dapat diamati bahwa antena yang tidak menggunakan struktur EBG memiliki efisiensi yang lebih besar pada daerah band-gap EBG dibandingkan dengan antena yang memiliki struktur EBG. Sesuai Gbr. 9, daerah band-gap EBG pada $g=1,55 \mathrm{~mm}$ adalah daerah yang berada di bawah area $S_{21}<-10 \mathrm{~dB}$, yaitu berkisar pada rentang $8,5 \mathrm{GHz}$ sampai $14 \mathrm{GHz}$.

Jika ditinjau dari parameter gain, gain maksimal terukur sebesar 5,3 dBi di frekuensi $9 \mathrm{GHz}$ pada konfigurasi antena awal tanpa menggunakan struktur EBG. Antena yang menggunakan struktur EBG, seperti dapat dilihat pada Gbr. 15, memiliki gain yang lebih kecil pada daerah band-gap. Hal tersebut terjadi karena nilai gain berbanding lurus dengan efisiensi antena, sehingga adanya daerah band-gap yang memiliki efisiensi kecil mengakibatkan nilai gain yang juga mengecil dibandingkan dengan antena tanpa band-gap. Namun, di luar daerah band-gap, seperti pada Gbr. 15, hasil akhir antena dengan struktur EBG dan triple notch band secara garis besar memiliki gain yang lebih besar dibandingkan antena yang lain. Gain maksimal yang terukur adalah sebesar 4,8 dBi pada frekuensi $14 \mathrm{GHz}$.

Pada radiasi medan jauh untuk antena UWB yang diusulkan, dilakukan pengukuran pada tiga frekuensi yang memiliki koefisien refleksi baik, yaitu pada frekuensi $4 \mathrm{GHz}, 9 \mathrm{GHz}$, dan
TABEL IV

Perbandingan ANTENa USUlan DENGan ANTENA LAIN

\begin{tabular}{|c|c|c|c|c|}
\hline $\begin{array}{c}\text { Referensi } \\
\text { Antena }\end{array}$ & $\begin{array}{c}\text { Dimensi Antena } \\
\left(\mathbf{m m}^{\mathbf{3}}\right)\end{array}$ & $\begin{array}{c}\text { Jumlah } \\
\text { Notch band }\end{array}$ & $\begin{array}{c}\text { Rentang } \\
\text { Frekuensi } \\
(\mathbf{G H z})\end{array}$ & $\begin{array}{c}\text { Lebar } \\
\text { Pita } \\
(\mathbf{G H z})\end{array}$ \\
\hline$[2]$ & $60 \times 60 \times 1,6$ & 3 & $1,75-11$ & 9,25 \\
\hline$[17]$ & $60 \times 40 \times 1,6$ & 3 & $2-10,6$ & 8,6 \\
\hline$[18]$ & $35 \times 35 \times 1,6$ & 3 & $1,95-12,92$ & 10,97 \\
\hline$[19]$ & $46 \times 36 \times 1,6$ & 3 & $3-11$ & 8 \\
\hline$[20]$ & $60 \times 78 \times 1,6$ & 3 & $1,5-15$ & 13,5 \\
\hline $\begin{array}{c}\text { Antena } \\
\text { yang } \\
\text { dirancang }\end{array}$ & $35,6 \times 27,3 \times 1,6$ & 3 & $2,86-16,08$ & 13,22 \\
\hline
\end{tabular}

14,8 GHz. Gbr. 16 menunjukan pola radiasi arah azimut dan elevasi ketiga frekuensi tersebut. Secara garis besar, dapat diperhatikan bahwa penambahan struktur EBG pada lapisan substrat yang sama dengan patch tidak terlalu mengubah bentuk pola radiasi antena sehingga peningkatan lebar pita dapat dilakukan tanpa mengubah parameter yang lain.

Pada tahap akhir, desain antena yang diusulkan dibandingkan dengan beberapa penelitian sebelumnya yang berkaitan dengan antena UWB dengan bahan yang sama (FR4) [2], [16]-[20], yang dikaji dari sisi dimensi keseluruhan, jumlah notch band, dan lebar pita keseluruhan. Pada Tabel IV dapat dilihat bahwa keseluruhan antena bekerja pada frekuensi UWB (3,1-10,6 GHz) dan memiliki jumlah notch band yang sama, yaitu tiga buah. Dari sisi dimensi, antena pada [16] menawarkan dimensi yang hampir sama dengan antena yang 
diusulkan, tetapi dengan lebar pita yang lebih sempit. Antena pada [18] memperlihatkan lebar pita yang lebih lebar dari antena yang diusulkan, tetapi memiliki kekurangan pada dimensi antena yang lebih besar. Dari Tabel IV, dapat disimpulkan bahwa antena yang diusulkan memiliki keunggulan, yaitu ukuran yang lebih kecil dan pita yang lebih lebar dibandingkan dengan antena referensi.

\section{KESIMPULAN}

Dalam penelitian antena UWB heksagonal dengan struktur EBG dan triple slot ini telah berhasil didapatkan antena UWB dengan lebar pita sampai $13,22 \mathrm{GHz}$ dan tiga buah notch band. Lebar pita dapat ditingkatkan dengan menggunakan struktur EBG heksagonal dengan slot ring untuk meningkatkan batas frekuensi atas, dari 10,6 GHz sampai 16,08 GHz. Tiga buah slot telah berhasil diintegrasikan untuk mendapatkan tiga frekuensi penolakan pada pita WLAN, satelit $X$-Band, dan juga DBS. Namun, seiring dengan penambahan jumlah notch band, penggunaan slot menjadi tidak efisien karena diperlukan lebih banyak jumlah slot dan titik penempatannya. Oleh karena itu, untuk jumlah notch band yang lebih banyak, diperlukan satu struktur yang dapat memberikan efek notch band lebih dari satu sekaligus.

\section{REFERENSI}

[1] First Report and Order in the Matter of Revision of Part 15 of the Commission's Rules Regarding Ultra-Wideband Transmission Systems, Federal Communication Commission ET-Docket 98-153, 2002.

[2] K. Nadeem, Z. Ahmed, I. Nadeem, F.B. Zarrabi, dan K. Alimgeer, "UWB Circular Monopole Antenna with Fractal Slots for Triple Band-Notch Characteristics," 2018 Int. Conf. on Frontiers of Inf. Technol. (FIT), 2018, hal. 271-274.

[3] A.A. Kadam, A.A. Deshmukh, K.P. Ray, dan S.B. Deshmukh, "Dua Band-notched UWB Antenna with L-shaped Slots and Triangular EBG Structures," 2019 IEEE Indian Conf. on Antennas and Prop. (InCAP), 2019, hal. 1-4.

[4] C. Wang, Y. Chen, dan S. Yang, "Bandwidth Enhancement of a DualPolarized Slot Antenna Using Characteristic Modes," IEEE Antennas and Wireless Prop. Lett., Vol. 17, No. 6, hal. 988-992, Jun. 2018.

[5] A. Raghavaraju, T.V. Ramakrishna, B.T.P Madhav, dan T. Bhavani, "Investigation on EBG Structured CPW Fed CM Antenna for WiMAX, WLAN Applications," 2019 Int. Conf. Vis. Towards Emerg. Trends in Commun. and Network. (ViTECoN), 2019, hal. 1-4

[6] R. Bappadittya, C. Santosh, dan A.K. Bhattacharjee, "Symmetrical Hexagonal Monopole Antenna with Bandwidth Enhancement Under
UWB Operations," Wireless Personal Communications, Vol. 108, hal.853-863, Mei 2019.

[7] S. Tripathi, A. Mohan, dan S. Yadav, "Hexagonal Fractal Ultra-wideband Antenna Using Koch Geometry with Bandwidth Enhancement," IET Microw., Antennas \& Prop., Vol. 8, No. 15, hal.1445-1450, Des. 2014.

[8] S. Kundu dan S.K. Jana, "A Leaf-shaped CPW-fed UWB Antenna for GPR Applications,” Wiley Microw. Opt Technol. Lett., Vol. 60, No. 4, hal. 941-945, Apr. 2018.

[9] R.W. Aldhaheri dan I.S. Alruhaili, "A Simple and Compact CPW-Fed UWB Antenna with WLAN Band Rejection," 2019 IEEE 19th Mediterranean Microw. Symp. (MMS), 2019, hal 1-4.

[10] M.A. Basit, G. Wen, O.G. Kwame, dan N. Rasool, "A Compact Wideband CPW-fed Hybrid Slot Antenna," IEEE - 3rd Asia-Pacific Conf. Antennas and Prop., 2014, hal. 57-60.

[11] K.P. Ray, "Design Aspects of Printed Monopole Antennas for Ultra-Wide Band Applications," Int. J. Antennas and Prop., Vol. 2008, hal. 1-8, Apr. 2008.

[12] D.S. Rao dan G. Immadi, "A Penta Band Notched Elliptical Planar Monopole Antenna for UWB Applications," Progress In Electromagn. Res. M, Vol. 93, hal. 53-66, Jun. 2020.

[13] Z. Guo, H. Tian, X. Wang, Q. Luo, dan Y. Ji, "Bandwidth Enhancement of Monopole UWB Antenna with New Slots and EBG Structures," IEEE Antennas and Wireless Prop. Lett., Vol. 12, hal. 1550-1553, Nov. 2013.

[14] R.C. Hadarig, M.E. de Cos, dan F. Las-Heras, "On the Bandwidth Enhancement of Patch Antenna Using EBG/AMC Structures,” 2012 6th European Conf. Antennas and Prop. (EUCAP), 2012, hal. 2853-2857.

[15] O. Ayop, and M.K.A. Rahim, "Analysis of Mushroom-like Electromagnetic Band Gap Structure Using Suspended Transmission Line Technique," 2011 IEEE Int. RF \& Microw. Conf., 2011, hal. 258261.

[16] K. Vijay, P.P. Bhavarthe, dan R. Surendra, "Tunable Triple BandNotched UWB Antenna Using Single EBG and Varactor Diode," Progress In Electromagn. Res. C, Vol. 110, hal. 181-195, Jan. 2021.

[17] A.C. Anju dan T. Shiney, "Triple Frequency Notch in UWB Antenna with Single Ring SRR Loading," Procedia Comp. Sci., Vol. 93, hal. 94-100, Des. 2016

[18] A. Salim, Y.S. Faouri, dan S. Baqaleb, "Compact UWB Bowtie Antenna with Triple Rejection Bands," 2020 11th Int. Conf. on Inf. and Commun. Sys. (ICICS), 2020, hal. 406-409.

[19] G. Kumar, S. Jain, M.D. Sharma, dan A. Yadav, "Designing of Triple Band Rejection CPW Feed Circular UWB Antenna," 2020 Int. Conf. on Wireless Commun. Sig. Proc. and Network. (WiSPNET), 2020, hal. 112 117.

[20] S. Sharma, S.A. Imam, B.K. Kanaujia, dan M.K. Khandelwal, "Bandwidth Enhancement with Multiple Notch Bands and CrossPolarization Suppression of Microstrip Patch Antenna for Modern Wireless Applications," Wireless Personal Commun., Vol. 98, hal. 25532568, Okt. 2017 